at $157^{\circ}$. It proved to be ethylamine hydrobromide. Calculated for $\mathrm{C}_{2} \mathrm{H}_{3} \mathrm{NH}_{2} \cdot \mathrm{HBr}: \mathrm{Br}, 62.59$. Found: $\mathrm{Br}, 62.43$.

Bromoaurate, coarse, red-brown prisms melting at $190^{\circ}$. Calculated for $\mathrm{C}_{2} \mathrm{H}_{5} \mathrm{NH}_{2} \cdot \mathrm{HBr} . \mathrm{AuBr}_{3}: \mathrm{Au}, 35.03$. Found: $\mathrm{Au}, 34.98$.

The second compound referred to is easily soluble in chloroform; on treating with water, insoluble carbon tetrabromide was formed. From boiling chloroform beautiful prismatic needles melting at $150^{\circ}$ were $o b-$ tained. Calculated for $\left(\mathrm{C}_{2} \mathrm{H}_{5} \mathrm{NH}_{2}\right)_{4} \mathrm{CBr}_{4}: \mathrm{Br}, 62.44$. Found: $\mathrm{Br}, 62.39$. These compounds will be more closely investigated.

Siatle, Washington.

[CONTRIBUTIONS FROM THE CHEMICAL LABORATORY OF THE UNIVERSITY OF WASIf[NGTON.]

\title{
THE ACTION OF DIIODOACETYLENE ON ORGANIC BASES.
}

\section{BY WILLIAM M. DRHN. \\ Received July 28, $19 \mathrm{I}$.}

Diiodoacetylene was first prepared by Berend from silver acetylide and iodine in ether solution. Biltz ${ }^{2}$ prepared it from calcium carbide and iodine in potassium iodide solution. $\mathrm{Nef}^{3}$ prepared it from tetraiodoethylene and acetylene diiodide ${ }^{4}$ by treatment with alkali alcoholates.

New Method of Preparation.-The following excels the above methods not only in the ease of preparation but also in the quality and quantity of the yields. Water is admitted from a dropping funnel to a flask containing calcium carbide, at such a rate that a steady stream of gas is generated. The acetylene is conducted into a flask containing a solution of potassium iodide and carrying a dropping funnel and an exit tube. ${ }^{5}$ A solution of sodium hypochlorite ${ }^{6}$ or sodium hypobromite, ${ }^{7}$ preferably the former, ${ }^{8}$ is admitted a drop at a time. By reaction with potassium iodide, the hypohalite yields a yellow or brown-red colored solution and this, with the acetylene, immediately forms a beautiful flocculent precipitate of the diiodoacetylene. The precipitate increases in volume until the potassium iodide is exhausted and finally forms, during the pas-

${ }^{1}$ Ann., 135, 256; cf. Baeyer, Ber., 18, 2274; also Nef, Ann., 298, 343.

2 Ber., 30, I202; cf. G. de Chalmot, Am. Chem. J., 19, 877 .

3 Ann., 298, 341.

4 Ibid., 298, 342 .

5 The unchanged excess of acetylene may be passed into a gas reservoir and later passed again through the solution.

- This is best prepared by dropping concentrated hydrochloric acid into a tlask containing potassium permanganate and passing the chlorine into a moderately concentrated solution of sodium hydroxide.

${ }^{7}$ For the best method of preparing sodium hypobromite, see THrs JournaL, 33,526 .

8 With sodium hypochlorite, acetylene does not precipitate at all; with sodium hypobromite it precipitates "an oil." G. de Chalmot, Am. Chem. J., 19, 878. 
sage of the acetylene, a white mass, conpletely filling the solution, but settling on standing. When the solution of potassium iodide loses its property of coloring by the addition of hypohalite or when an excess of acetylene has passed through the mixture, the white crystals are filtered from the solution, washed with water and dried on clay plates. From Ioo g. of potassium iodide, $78 \mathrm{~g}$. of crystals melting at $79^{\circ}$ were obtained. The theoretical yield was $89 \mathrm{~g}$. By dissolving in low-boiling ligroin, ${ }^{1}$ drying with calcium chloride, and cooling with ice-water, crystals melting at $81^{\circ}$ were obtained. Calculated for $\mathrm{C}_{2} \mathrm{I}_{2}: \mathrm{I}, 9 \mathrm{I} .36$. Found: I, 9 I.33.

The reactions involved in the preparation of diiodoacetylene are:

$$
\begin{aligned}
& \mathrm{CaC}+2 \mathrm{H}_{2} \mathrm{O} \longrightarrow \mathrm{Ca}(\mathrm{OH})_{2}+\mathrm{C}_{2} \mathrm{H}_{2} \\
& \mathrm{KI}+\mathrm{NaOCl} \longrightarrow \mathrm{KCl}+\mathrm{NaOI} \\
& 2 \mathrm{NaOI}+\mathrm{C}_{2} \mathrm{H}_{2} \longrightarrow 2 \mathrm{NaOH}+\mathrm{C}_{2} \mathrm{I}_{2}
\end{aligned}
$$

Since sodium hypoiodite is quickly decomposed in accordance with the reactions

$$
\begin{aligned}
& 3 \mathrm{NaOI} \longrightarrow 2 \mathrm{NaI}+\mathrm{NaIO}_{3}, \\
& \mathrm{NaOI}+3 \mathrm{NaOCl}+\mathrm{NaOH}+\mathrm{H}_{2} \mathrm{O} \longrightarrow 3 \mathrm{NaCl}+\mathrm{H}_{3} \mathrm{Na}_{2} \mathrm{IO}_{6},
\end{aligned}
$$

some of the iodine is not converted into diiodoacetylene. Furthermore, some of the latter is also lost owing to its being volatil and also somewhat soluble in water. However, since diiodoacetylene is directiy obtainable from acetylene in the manner described and in 80-90 per cent. yields, the advantages of this method of preparation are evident.

It was anticipated that diodoacetylene is more reactive than is indicated by the reactions found in the literature. From experiments herewith contributed and from indications of other experiments under way, this surmize has been found to be correct. Diiodoacetylene reacts with organic bases in a manner analogous to the reaction of carbon tetrabromide on organic bases, yielding, most commonly, an aggregate of the base with two molecules of the diiodoacetylene.

Triethylamine and Diiodoacetylene.-When concentrated ether solutions of the two substances in molecular proportions were brought together, white feathery clusters of needles were formed after some time. On filtering, washing with ether, and drying on a clay plate, the crystals became light yellow in color. The substance darkens at $97^{\circ}$, blackens at $104^{\circ}$, and melts at $\mathrm{II} 5^{\circ}$. It is quite readily volatil and somewhat soluble in water with a neutral reaction.

$$
\begin{array}{ll}
\text { Calculated for }\left(\mathrm{C}_{2} \mathrm{H}_{6}\right)_{3} \mathrm{~N}\left(\mathrm{C}_{2} \mathrm{I}_{2}\right)_{2}: & \mathrm{N}, 2 . \mathrm{I}_{3} ; \mathrm{I}, 77.29 . \\
\text { Found: } & \mathrm{N}, 2.20 ; \mathrm{I}, 77 . \mathrm{I}_{3} .
\end{array}
$$

The decomposition of tristhylamine diiodoacetylene has not been studied.

Dipropylamine and Dirodoacetylene.-An ether solution of the sub'Biltz, Ber., 30, I203. Nef, Ann., 298, 344. 
stances in molecular proportions was prepared. The solution became red-violet in color and then long needles separated. They melted sharply at $160^{\circ}$.

$$
\begin{aligned}
& \text { Calculated for }\left(\mathrm{C}_{8} \mathrm{H}_{7}\right)_{2} \mathrm{NH}\left(\mathrm{C}_{2} \mathrm{I}_{2}\right)_{2}: \mathrm{N}, 2 . \mathrm{r}_{3} ; \mathrm{I}, 77.99 . \\
& \begin{array}{ll}
\text { Found: } & \mathrm{N}, 2.23 ; \mathrm{I}, 77.19 .
\end{array}
\end{aligned}
$$

Piperidine and Diiodoacetylene. - When the two substances were brought together without the use of a solvent, they reacted with explosive violence and yielded a black solid mass. In ordinary ether solution the mixture yielded first an amber-colored solution, then a violet solution, and finally precipitated a gummy mass. In anhydrous ether solution, colorless needles, darkening at $117^{\circ}$ and melting at $161^{\circ}$, were obtained. Calculated for $\mathrm{C}_{5} \mathrm{H}_{11} \mathrm{~N}\left(\mathrm{C}_{2} \mathrm{I}_{2}\right)_{2}$ : I, 79.23. Found: I, 79.62.

Phenylhydrazine and Diiodoacetylene.--It was found that phenylhydrazine reacted with diiodoacetylene in an anomalous manner. Products this far isolated are two hydroiodides of phenylhydrazine, phenylacetylene iodide, and elementary nitrogen.

When equimolecular quantities of phenylhydrazine and diiodoacetylene were dissolved in a small quantity of ether and the mixture was permitted to stand for a few hours, the color of the solution changed through light yellow and amber to dark red-brown, nitrogen was evolved and a matted mass of white crystals was obtained. The yield was greatly increased when two molecules of phenylhydrazine reacted with one molecule of diiodoacetylene. On filtering and recrystallizing from glacial acetic acid, needles of a beautiful luster were obtained.

Calculated for $\left(\mathrm{C}_{6} \mathrm{H}_{5} \mathrm{~N}_{2} \mathrm{H}_{3}\right)_{2} \mathrm{HI}: \mathrm{C}_{4} 4 \mathrm{r} .85 ; \mathrm{H}, 4.98 ; \mathrm{N}, 16.29 ; \mathrm{I}, 36.88$.

Found:

C, $41.76 ; \mathrm{H}, 4.70 ; \mathrm{N}, 16.30 ; \mathrm{I}, 36.79$.

This hydriodide of phenylhydrazine melts with decomposition at about $128^{\circ}$ and changes on standing in sunlight or on heating to the form of salt described below.

When the reaction mixture of phenylhydrazine and diiodoacetylene, prepared as described above and containing the needles, is permitted to stand for a number of days, or better, is heated for a few hours on the water bath under a return condenser, much nitrogen is evolved and the needles were replaced by a lesser volume of scale-like crystals. After filtering, washing with ether, and recrystallizing from glacial acetic acid, flaky mother-of-pearl crystals were obtained.

$$
\begin{aligned}
& \text { Calculated for } \mathrm{C}_{8} \mathrm{H}_{5} \mathrm{~N}_{2} \mathrm{H}_{3} . \mathrm{HI}: \mathrm{N} \text {, I I .87; I, } 53.79 \text {. } \\
& \text { Found: } \\
& \text { N, II. } 57 ; \text { I, } 53.64 \text {. }
\end{aligned}
$$

This hydriodide of phenylhydrazine darkens at $270^{\circ}$ but does not melt at $300^{\circ}$. When $39 \mathrm{~g}$. of $\mathrm{C}_{2} \mathrm{I}_{2}$ and $3 \mathrm{I}$ g. of $\mathrm{C}_{6} \mathrm{H}_{5} \mathrm{~N}_{2} \mathrm{H}_{3}$ were used, $24 \mathrm{~g}$. of $\mathrm{C}_{8} \mathrm{H}_{5} \mathrm{~N}_{2} \mathrm{H}_{3} \mathrm{HI}$ or $3 / 4$ mol. was obtained.

When $7 \mathrm{~g}$. of $\mathrm{C}_{2} \mathrm{I}_{2}$ and $5.5 \mathrm{~g}$. of $\mathrm{C}_{3} \mathrm{H}_{5} \mathrm{~N}_{2} \mathrm{H}_{3}$ reacted, $750 \mathrm{cc}$. of nitrogen were evolved; this is equal to 57 per cent. of the total nitrogen. 
The ether solution was evaporated and a red oil of a peculiar odor was obtained. It was fractionated in vacuo. The larger fraction boiled at $144^{\circ}$ and $26 \mathrm{~mm}$. A number of analyses indicated that the oil is a mixture, approximating the percentages of composition of $\mathrm{C}_{6} \mathrm{H}_{5} \mathrm{C} \equiv \mathrm{CI}$; however, since all the products cannot be accounted for by an equation, such as:

${ }_{2} \mathrm{C}_{6} \mathrm{H}_{5} \mathrm{NHNH}_{2}+\mathrm{C}_{2} \mathrm{I}_{2} \longrightarrow \mathrm{C}_{6} \mathrm{H}_{5} \mathrm{NHNH}_{2} \mathrm{HI}+\mathrm{C}_{6} \mathrm{H}_{5} \mathrm{C} \equiv \mathrm{CI}+\mathrm{N}_{2}+\mathrm{H}_{2}$, other experiments must be made.

Other bases than the above-mentioned react with diiodoacetylene in ether solution and give well characterized crystallin products. These will be discussed in a future contribution.

ShattLe, Washington.

[Fron the Laboratory of Physiological Chemistry of the University of IlliNoIs.]

FASTING STUDIES: IV (STUDIES ON WATER DRINKING: VII). ON THE ALLANTOIN AND PURINE EXCRETION OF FASTING DOGS.

By S. R. WRBATh AND P. B. HAWR.

Received July 25, 191.

Introduction.

The occurrence of allantoin as a urinary constituent was first demonstrated by Wöhler. ${ }^{1}$ He found it to be present in the urine of suckling calves in sufficient quantity to separate out in crystallin form. The role played by allantoin in the metabolic processes of the animal organism, however, did not receive serious attention until about $5^{\circ}$ years after Wöhler had made his pioneer observation. In fact for years it was believed that allantoin was confined, as an excretory product, to the urine of infants and the young of certain species of lower animals, among them the calf, as already mentioned.

It was early known, of course, that allantoin could be produced in zitro by the oxidation of uric acid. With this relation in mind, Wöhler and Frerichs ${ }^{2}$ fed uric acid to dogs and rabbits as well as to men and searched for allantoin in the urine of the subjects. They were unsuccessful in their attempts to isolate the substance and consequently came to the conclusion that the uric acid which they had fed had undergone a profound oxidation in the animal body and that the final oxidation products were unknown substances below the allantoin stage. Several years later Neubauer ${ }^{3}$ likewise made an unsuccessful attempt to demonstrate the presence of allantoin in the urine of rabbits after uric acid

'Wöhler, Ann., 70, 229 (1849).

2 Ann., 65, 335 (1848).

"Ibid., 99, 2 I 7 (1 856$)$. 